\section{Prehistoric Implements in the Transvaal and Orange River Colony.}

THE reason for writing these short notes is the desire to point out to those with the requisite knowledge the places where what are probably palæolithic remains can be found in South Africa. I am not able to dilate on the technical side of the question, having only a smattering of the subject.

Being a volunteer in the British Army, the immense distances covered by us gave one an opportunity of seeing a larger tract of country than would be possible as a civilian. Unfortunately, in South Africa the amount of systematic research into the subject of prehistoric weapons has been but small, and I think the Orange River Colony and the Transvaal would be found very rich in all such remains. The heavy rains and nature of the country allow many glimpses of the geological formations, and the dongas and dry river banks will nearly always reveal some old "drift." The nature of our marching did not allow us to go far from the beaten road, but a few worked stones could be picked up in every day's march.

Starting at Sterkstroom, with the $3^{\text {rd }}$ Division, such specimens can be found all round the town of about 2 inches in length in a fair state of preservation, some few showing the effect of being water-worn. At a coal mine named Wallsend, the hill where we camped is simply covered with scrapers and chips; in fact I collected quite a dozen in the small circle covered by our bell tent. Further north, at Bethulie Bridge, they are lying in the subsoil of the river bank, as well as in the stony reaches of the river. Springfontein, Smithfield, Dewetsdorp, in fact right up to Bloemfontein, the country is covered with stones all about the same size, roughly chipped and, in all probability, of palreolithic origin. They are of the leaf form and vary from $I$ to $2 \frac{1}{2}$ inches in length.

At the Vaal River they were more water-worn and larger, about 5 by 2 inches. Better specimens could probably be obtained by examining the drift, which I myself had no opportunity of doing. I found only two or three specimens round about Pretoria. Middleburg and Belfast were the last two places I was in, and in the former an immense quantity of implements can be picked up in the river bed and in the subsoil adjoining. They are of the large size, as those in the Vaal River, some which I found being about 5 by 5 inches and quite I inch thick.

Unfortunately, Army regulations as to the weight of kit had to be carried out, and I had three separate times to throw my collection away. I had kept the best specimens and ticketed them, but in the end I found myself discharged from the Army as a time-expired volunteer in Cape Town, with only three or four dilapidated specimens from Belfast.

If regulars and volunteers would write about their observations of other parts of the country covered by them it would indicate at a glance the richest places where a systematic re. search could be undertaken with the best possible results.

Sunderland.

STANLEY B. HuT'

\section{The Age of the Woburn Abbey Musk-Ox.}

IN the notice of the young musk-ox at Woburn Abbey which appeared in NATURE of May 16 it was stated that the animal was considerably more than two years of age when the photograph was taken. This age was assigned on account of a statement made by Dr. Allen in his recent memoir on the Greenland and American musk-oxen that the Woburn specimens must have been yearlings when they were first photographed in I899. His reason for making that statement were that a young calf captured at Fort Conder in May, 1899, had a black face, instead of the white-spotted faces of the Woburn animals ; and that the latter had consequently changed their coats. Now the Woburn specimens were captured on Clavering Island on August 16 of that year, and from information that has recently been supplied to me it seems almost certain that they were calves of that year, probably born the preceding April or May. If this be so, and if calves have black faces when first born, it would seem that the Woburn specimens had already,changed their first coats when shipped for England during the late summer, a photograph of them having been taken on board ship showing the white faces. It thus appears that when the photograph reproduced in NATURE was taken, the animal was not more than two years old, and possibly rather less.

NO. I 648 , vOL. 64$]$
The Subjective Lowering of Pitch.

As a general rule, the pitch of a musical note does not in any way depend upon its intensity, but solely upon the wave-length. It appears probable, however, that any wave motion of very great intensity produces distorted effects. Thus we find that a very loud sound may so affect the ear of the observer as to appear flatter than it really is. This is a purely subjective effect.

Mr. Burton was, I believe, the first to investigate the phenomenon, and some of his results (together with his explanation of them) will be found in vol. xiii. of the Proceedings of the Physical Society. My own attention was first drawn to the matter by observing what appeared to be the false intonation of certain singers upon loud notes, either when I was conducting near those singers or when I was rehearsing in a small room. Reading then of Dr. Burton's researches, I was led to investigate them for myself.

The subjective lowering of pitch is an undoubted fact, i.e. a very loud note does appear flatter than it really is.

If a $\mathrm{C}$ tuning-fork (middle C, 256 vibrations per second) be strongly bowed, and then be quickly brought near the ear, before its loud note has had time to die away, the sound will appear flattened to about $\mathrm{B}_{b_{1}}$, or even $\mathrm{A}_{1}$, the amount of the effect being different to different ears.

It is more difficult to obtain the effect with higher forks indeed, a $\mathrm{C}^{\mathrm{l}}$ fork $\left(5^{12}\right)$ must be bowed very strongly indeed to give the effect at all. An E fork (320) appears to give a flat $\mathrm{D}=$, and a $\mathrm{G}$ fork $\left(3^{84}\right)$ gives $\mathrm{F}$.

The effect is a subjective one, caused by great intensity, for it vanishes as the sound gets softer, and can then be restored by bringing the fork nearer the ear, thus again increasing the intensity. In this last case the restoration of effect is sudden, and is not due to any gradual movement of the fork (Doppler's principle).

If the position of the source of sound be fixed, the subjective note gets sharper as the intensity of the vibrations gets less; for instance, an E fork (320), when very strongly bowed, gave C. as its subjective note; but, as the vibrations died down, this $\mathrm{C}_{\mathrm{p}}^{\mathrm{H}}$ varied to $\mathrm{D}$, then became $\mathrm{E} b$, and finally and suddenly stopped altogether.

The amount of the subjective effect differs with different in. dividuals, both in pitch and in intensity. What to one person appears a flattening of a minor 3 rd, to another auditor appears a flattening of only a major 2nd, but in every case it appears to be a flattening and not a sharpening. Also the loudness of the subjective note appears different, even to the different ears of the same person.

In the case of some organ-pipes tested, the following results were obtained :-

C pipe (open, 256) gave $A_{1}$ as subjective.

$\mathrm{E}$ pipe (open, 320) gave $\mathrm{D}$ as subjective.

$\mathrm{G}$ pipe (open, 384) gave $\mathrm{F}$ as subjective.

$\mathrm{C}^{\mathrm{l}}$ pipe (open, $5^{\mathrm{I} 2}$ ) gave $\mathrm{B}$ as subjective.

If an ear-trumpet be used, a very loud source of sound is not necessary in order to obtain subjective effects. If the source of sound be placed at a distance just great enough to prevent subjective flattening, and then an ear-trumpet be used, the subjective note at once appears.

Much of my own musical work has been done amongst male voices, and I have frequently noticed that a singer of good concert-room power may, if practising in a small room, seemingly sing with flat intonation. I should be glad to have further experience concerning this from your contributors, who will also, I hope, have noticed the effect in the case of brass instruments.

Normal College, Bangor, May I 5

E. Hurren Harding.

\section{RECENT STUDIES OF OLD ITALIAN \\ VOLCANOES.}

THE abundant and well-preserved extinct volcanoes of Italy have long had a great fascination for students of geology. So many allusions to them are scattered through the literature of the science, and so many accounts of them, more or less brief, have been furnished by those who have visited them, that their general characters and the more important varieties of their rocks are now tolerably familiar. But until lately hardly 